Ewa Zalewska

ORCID: 0000-0002-8964-7286

Akademia Marynarki Wojennej w Gdyni

e.zalewska@amw.gdynia.pl

\title{
Niemieckie podręczniki do nauczania religii jako środki kształtowania tożsamości religijnej dziecka w wieku młodszoszkolnym
}

\section{Summary \\ German textbooks for religious instruction as a means of shaping the religious identity of a younger school-age child}

The issue raised in the text concerns the role that German textbooks for religious instruction play in shaping the identity of a child from the initial classes. The first part defines the key concept: religious identity. Modern contexts of religious socialization and the resulting challenges to the educational process were also recalled. In the second part, based on the results of the analysis of textbooks, the conclusion about the positive meaning of these books was formulated as a means of supporting the development of the individual and social aspect of the child's religious identity and shaping a reflective and at the same time affirmative attitude towards religion.

Keywords: religious teaching, religious identity, school textbook

Słowa kluczowe: nauczanie religii, tożsamość religijna, podręcznik szkolny

Zagadnienie poruszone w artykule dotyczy roli, jaką w kształtowaniu tożsamości dziecka $\mathrm{z}$ klas początkowych odgrywają niemieckie podręczniki do nauczania religii. $\mathrm{W}$ jego pierwszej części zdefiniowano kluczowe pojęcie „,tożsamość religijna”. Przywołano także współczesne konteksty socjalizacji religijnej i wynikające z nich wyzwania dla procesu edukacyjnego. W części drugiej, opierając się na wynikach przeprowadzonej analizy podręczników, sformułowano wniosek o pozytywnym znaczeniu tych książek jako środków wspierania rozwoju indywidualnego i społecznego aspektu tożsamości religijnej dziecka oraz kształtowania refleksyjnej i zarazem afirmatywnej postawy wobec wyznawanej religii.

W niemieckich szkołach publicznych nauczanie religii ma charakter obligatoryjny ${ }^{1}$. Uczeń może wybierać, zgodnie z własnymi preferencjami wyznaniowymi, spośród bogatej oferty edukacyjnej, zarówno jeśli chodzi o nauczanie konfesyjne, jak i przedmio-

\footnotetext{
1 O takim statusie nauczania religii w szkole stanowi Konstytucja (art. 7, p. 3). Przedmioty, na których realizuje się ten obowiązek, adresowane są zarówno do dzieci wierzących, jak i niewierzących. Wybór pozostaje w gestii uczniów lub ich rodziców.
} 
ty alternatywne o profilu etyczno-normatywnym przeznaczone dla osób niewierzących (Drobinski, Schulte von Drach 2016: 1). Te ostatnie skupiają się na przekazie wiedzy o różnych religiach i ich historycznym oraz współczesnym znaczeniu dla społeczeństwa i kultury. Warto przy tym podkreślić, że niezależnie od swej neutralności religijnej i światopoglądowej niemieckie demokratyczne państwo ma obowiązek respektowania wolności wyznania swoich obywateli. Podstawowy cel edukacji religijnej - kształtowanie tożsamości religijnej uczniów - jest realizowany z pełnym poszanowaniem ich podmiotowości w warunkach wyznaczonych przez polifoniczny charakter niemieckiego społeczeństwa i jego postępującą sekularyzację. Sytuacja ta wiąże się z wieloma wyzwaniami wobec konfesyjnego nauczania religii i rodzi pytanie o efektywne strategie wspierania rozwoju religijnego ucznia. Współobecność zaangażowanego religijnie nauczyciela pełniącego funkcję przewodnika i wierzących rówieśników postrzegana jest jako sprzyjająca umacnianiu i rozwijaniu własnej wiary, podejmowaniu refleksji nad powinnościami wynikającymi z jej aksjomatów, inicjowaniu przeżyć natury religijnej, wymianie doświadczeń, a także - co niezwykle istotne - artykułowaniu pytań natury religijnej i poszukiwaniu na nie odpowiedzi.

Wykorzystanie zasygnalizowanego potencjału konfesyjnego modelu nauczania religii wymaga doboru odpowiednich treści, metod i form kształcenia. W tym kontekście podręcznik szkolny jako środek ich przełożenia na grunt praktyk edukacyjnych ma szczególne znaczenie. W związku z tym należy postawić pytanie o rolę podręczników do nauczania religii w procesie krystalizowania się religijnej tożsamości ucznia. Za przedmiot empirycznych analiz mających odpowiedzieć na to pytanie przyjęto podręczniki religii katolickiej, protestanckiej i islamu do klas początkowych. Etap ten obejmuje w Niemczech cztery pierwsze lata nauki, którą dzieci rozpoczynają po ukończeniu szóstego roku życia. Stanowią one ważną fazę religijnego rozwoju człowieka związaną z ,alfabetyzacją symboliczno-religijną”, chodzi w niej o „możliwości wyrażania się za pomocą różnych doświadczeń religijnych, np. święta, tradycje czy uczestnictwo w praktykach religijnych. Ma tu też miejsce proces rozumienia symboli religijnych czy innych elementów należących do kultu religijnego. W tym czasie następuje też poznawanie różnych tekstów religijnych czy dzieł sztuki, które zostały zainspirowane religią" (Orłowska 2012: 135-136).

\section{Kształtowanie tożsamości religijnej jako zadanie podmiotu i wyzwanie dla edukacji religijnej}

Tożsamość to termin, który pochodzi z języka łacińskiego: idem oznacza identyczność, ciągłość (Krasowska 2013: 110). Aktualnie zarysowały się dwa stanowiska dotyczące jej istoty i procesu konstytuowania się. Zwolennicy pierwszego, odwołując się do semantycznej genezy tej kategorii, wskazują na fazowy i społecznie zdeterminowany przebieg rozwoju tożsamości i jej spójny charakter (jako przykład można wskazać koncepcje J. Piageta i L. Kohlberga), natomiast przedstawiciele drugiego, odnosząc się do polifoniczności i nieprzewidywalności współczesnej rzeczywistości, określają tożsamość podmiotów jako 
„rozproszoną” i do jej opisu używają terminu „Patchwork sttat Idenntität” (Schweitzer 2005: 295). Jeżeli taka konstatacja co do natury tożsamości jednostek żyjących w XXI w. jest zasadna, generuje to problem o charakterze pedagogicznym dotyczący strategii przeciwdziałania jej dekonstrukcji. Należy przy tym dodać, że w sytuacji postępującej dezintegracji rzeczywistości ujawnia się znaczenie religii jako obszaru przywracania poznawczego i aksjologicznego ładu. Pełni ona bowiem funkcję „uniwersum znaczeniowego" (Berger, Luckman 1983: 172), ,nadaje sens ludzkim działaniom w strukturze społecznej, jednocześnie je legitymizując” (Piechniczek 2015: 32), łączy „w jedną wspólnotę moralną" (Dobbelare 2012: 149) wszystkich swoich wyznawców.

Czym zatem jest tożsamość religijna? W szerszym znaczeniu - uniwersalnym - jest jednym z elementów tożsamości każdego człowieka. Wiąże się z jego stosunkiem do religii (niezależnie od tego, czy ma on charakter afirmatywny czy wrogi). W węższym znaczeniu termin ten dotyczy osoby wierzącej i oznacza: „Wieloaspektowy sposób rozumienia oraz kształtowania własnej egzystencji, a także otaczającej rzeczywistości przez pryzmat osobistego doświadczenia wiary i wspólnotowych sposobów jej wyrażania w obrzędach i przekazie, czyli religii, do której się należy” (Różańska 2009: 37). W tworzeniu się tożsamości religijnej znaczenie mają dwa przemienne procesy: eksploracji związanej z nabywaniem wiedzy o określonej religii oraz zobowiązania, w którego toku następuje internalizacja jej wartości jako podstaw własnego działania lub jej odrzucenia i zwrócenia się ku innej religii (Pankalla, Wieradzka 2014: 169-174).

Na podstawie tego opisu można sformułować dwa podstawowe postulaty pod adresem edukacji religijnej. Po pierwsze tożsamość religijną uczniów należy traktować nie jako nadaną (wynikającą z jego przynależności do określonej wspólnoty wyznaniowej), ale jako zadaną - formującą się w toku długotrwałego procesu dzięki osobistej aktywności podmiotu poszukującego punktu odniesienia dla swej egzystencji, podejmującego refleksję nad sensem istnienia oraz zobowiązaniami i powinnościami wobec siebie i innych, wynikającymi z aprobowanej konfesji. Po drugie, w wyniku nawiązania do gwarantowanej uczniom możliwości formułowania odpowiedzi na własne pytania religijne i postrzegania ich „pytajności” jako ważnej kategorii edukacji skoncentrowanej wokół uczniowskiego samostanowienia, trzeba odrzucić jej transmisyjny model. Podstawowy zarzut kierowany pod jego adresem dotyczy ograniczenia możliwości dialogu z obszarem wybranego sacrum - co jest niezwykle ważne w ustanawianiu intymnej i osobistej relacji podmiotu $\mathrm{z}$ wybraną konfesją, ponieważ „w wychowaniu religijnym nie chodzi (...) w pierwszym rzędzie o transmisję doktrynalnych prawd, ale o wyksztalcenie religijnego sposobu samorozumienia, orientacji i działania" (Milerski 2003: 276). Tradycyjny model nauczania religii rodzi zatem uzasadnione wątpliwości co do zbudowania przez uczniów integralnej tożsamości religijnej. Składa się ona bowiem z trzech komponentów: kognitywnego, odnoszącego się do posiadanej wiedzy religijnej; emocjonalnego związanego ze sferą osobistych doświadczeń i przeżyć natury religijnej; behawioralnego dotyczącego praktyk religijnych jednostki oraz ról podejmowanych w obszarze wspólnoty wyznaniowej i społeczeństwie (Krasowska 2013: 110). Ponadto trzeba podkreślić, że w każdej tożsamości 
religijnej zaznaczają się zarówno obecność elementów specyficznych dla wyznawanej konfesji, jak i wspólnych z innymi wyznaniami. Forma ich ekspozycji ma ogromne znaczenie dla uczniowskich sposobów recepcji inności i odmienności (nie tylko religijnej) i może generować całe spektrum postaw - od akceptacji po wrogość i odrzucenie.

Analizując kontekstowe uwarunkowania procesu socjalizacji religijnej w demokratycznych Niemczech, można określić tożsamość podmiotów jako rezultat działania różnych czynników społecznych, politycznych i kulturowych. Sfera publiczna w Niemczech ma charakter polidyskursywny, polikonfesyjny i polietniczny, jednocześnie zaś podlega wszechobecnemu procesowi globalizacji. Pojawiają się w związku z tym obawy, że: „Proces uniwersalizacji kulturowej i liberalizacji indywidualnych wyborów tożsamościowych, charakterystyczny dla ponowoczesności, osłabia kulturowe podstawy wyodrębniania wspólnoty narodowej" (Kobzarska-Bar 2012: 120). W tym kontekście ujawnia się kwestia bezpieczeństwa kulturowego i bezpieczeństwa konfesyjnego. To pierwsze ,jest traktowane przede wszystkim jako możliwość zachowania przez spoleczeństwo własnej specyfiki (...) powyższe pojęcie obejmuje stałość tradycyjnych schematów języka, kultury, tożsamość, społeczność; zwyczajów narodowych i religijnych" (Herbatski 2015: 138). W odpowiedzi na pytanie o kanon kulturowy, który współcześnie mógłby stanowić podstawę zbiorowej i indywidualnej tożsamości, Bassman Tibi wprowadził pojęcie „kultura wiodąca" (Leitkultur) - jej elementem składowym jest wolność wyznania religijnego. Polikonfesyjność niemieckiego społeczeństwa rodzi jednak określone problemy, współwystępowanie różnych religii sprawia, ,że nasze uniwersum nie jest jedynym możliwym” (Berger, Luckmann 1983: 173). Pojawiają się w związku tym obawy o bezpieczeństwo konfesyjne, o „system zachowania głównej zawartości jakiejkolwiek konfesji i jej osobliwości kulturowych, a także zażegnanie konfliktów na gruncie konfesyjnym" (Herbatski 2015: 146). Religijny pluralizm z jednej strony stwarza jednostce możliwość wyboru, z drugiej jednak sprzyja także aktom konwersji. Zwłaszcza że obecnie w procesie socjalizacji mamy do czynienia ze zjawiskiem kryzysu tożsamości religijnej dziedziczonej na drodze międzypokoleniowego przekazu wiary i wartości. Chodzi nie tylko o sekularyzację społeczeństwa niemieckiego, ale także o dewaluację pewnych tradycyjnych form religii i religijności.

Z kolei potrzeba odwołania się do przejrzystego ładu aksjologicznego i poznawczego niejednokrotnie prowadzi do „absolutyzacji konkretnej duchowości, usztywniania tożsamości religijnej” (Szczyrba 2001: 271). Tendencja ta ujawnia się w Niemczech zwłaszcza wśród mniejszości etnicznych i religijnych - przeżywających trudności natury asymilacyjnej i spotykających się z przejawami wrogości - poszukują one wsparcia na gruncie własnej tradycji, kultury i konfesji.

Warto jednak dostrzec znaczenie obecności Innego nie tylko w kontekście sygnalizowanego już niebezpieczeństwa konwersji, ale także krystalizowania się (umacniania) własnej tożsamości religijnej. Wspólistnienie wielu religii (i kultur) w przestrzeni publicznej co prawda może prowadzić do ich dyfuzji, homogenizacji i tym samym - rozmycia tożsamości podmiotowej i zbiorowej, ale zarazem zapobiega stagnacji i izolacji, zachęca do 
refleksji nad swoją tożsamością, rozważenia „znaczenia własnej obecności w świecie i dla świata" (Szczyrba 2001: 273). W tym procesie Inny może być tym, od którego się uczymy, impulsem do głębszych rozważań nad własną religią, może zmienić optykę jej oglądu. Konfrontując swoje stanowisko z założeniami innej konfesji, podmiot jest motywowany do krytycznego namysłu, może konstruować ważkie i dobrze uzasadnione argumenty na rzecz swego dotychczasowego wyboru, co chroni zarówno przed powierzchowną recepcją własnego sacrum, jak i pochopnym zaakceptowaniem innej konfesji jako nowego obszaru autoidentyfikacji.

Nawiązując do klasyfikacji typów tożsamości religijnej Samaweera Veerasamy, można uznać, że w opisanym polu napięć, którego granice wyznaczają niebezpieczeństwo konwersji i religijny fundamentalizm, szczególne znaczenie zyskuje „typ poszukujący”. Newralgiczne punkty jego charakterystyki stanowią: refleksyjny stosunek do własnej konfesji, budowanie osobistej (zindywidualizowanej) relacji $\mathrm{z}$ afirmowanym sacrum (kluczową rolę odgrywają tu własne doświadczenia), zainteresowanie różnymi religiami i pozytywny stosunek do ich wyznawców (Wieradzka-Pilarczyk 2015: 95). Konfrontując tę charakterystykę z ogólnymi celami nauczania religii i zaleceniami sformułowanymi przez gremia katolickie uczestniczące w projektowaniu edukacji religijnej, można dostrzec ich wspólny rdzeń. Podkreśla się bowiem potrzebę: budowania pozytywnego stosunku do wybranej konfesji opartego na rzetelnej wiedzy o niej (ta rzetelność obowiązuje także przy tworzeniu wizerunków innych konfesji), afirmacji związanych z nią wartości i akceptacji sposobu życia, integracji sfery sacrum i profanum jako ważnych przestrzeni doświadczeń uczniowskich i obszarów praktykowania nakazów wiary, inspirujących do stawiania pytań natury egzystencjalnej i religijnej.

\section{Podręczniki do nauczania religii jako przewodniki dziecka na drodze kształtowania tożsamości religijnej}

W ramach prowadzonych empirycznych poszukiwań zastosowano dyskursywno-analityczna perspektywę metodologiczna (Höhne 2003; Zalewska 2013), w której podręcznik traktowany jest jako medium dystrybucji określonych dyskursów publicznych na grunt praktyk edukacyjnych, a na plan pierwszy wysuwa się jego funkcja społeczna - socjalizacyjna (Zalewska 2013: 65-78). Analiza dyskursu opiera się na „,badaniu relacji między strukturami tekstu (...) a strukturami i procesami społecznymi, politycznymi i kulturowymi” (Polkowska 2001: 132). Odwołując się do tej definicji, można określić główny cel przeprowadzonych badań - rozpoznanie podstawowych wymiarów (dyskursywnych) koncepcji edukacji religijnej z kart podręczników i określenie wagi jej realizacji kształtowania tożsamości religijnej adresatów (uczniów). Wymagało to:

- rekonstrukcji strategii nauczania/ uczenia się „wpisanych” w metodyczną obudowę podręczników, co jest istotne w określeniu zakresu uczniowskiej aktywności i autonomii poznawczej w toku krystalizowania się jego tożsamości religijnej; 
- analizy merytorycznej płaszczyzny podręczników pod kątem rzetelności, aktualności i ważności prezentowanego w nich obrazu rzeczywistości społecznej szczególnie jej religijnego aspektu, wymienione cechy konstytutywne sprzyjają bowiem kształtowaniu postaw świadomego i refleksyjnego uczestnictwa w życiu społecznym i religijnym.

Ze względu na ograniczenia wynikające z rozmiaru tego tekstu referowanie wyników badań ma charakter skrótowy i ogranicza się do prezentacji podstawowych i najważniejszych wniosków.

Fundament koncepcji metodycznej i merytorycznej płaszczyzny podręcznika stanowią:

1. Orientacja podmiotowa w odniesieniu do statusu ucznia, generowana zarówno przez założenia humanistycznej (personalistycznej) filozofii, w której podkreśla się integralność i indywidualność (niepowtarzalność) jednostki, jak i konstruktywistyczne strategie uczenia się, dzięki którym proces budowania tożsamości religijnej ma dynamiczny i otwarty charakter, wymaga aktywnej i refleksyjnej postawy ucznia, staje się jego osobistym zadaniem (którego realizacja będzie trwać przez całe życie).

2. Wielowymiarowy i zróżnicowany obraz sfery sacrum i profanum; tematyka bliska jest dziecku (zarówno ze względu na wiek, jak i doświadczenia społeczne), dominuje rzeczowy i obiektywny charakter podręcznikowej narracji, prezentowane są dylematy i rozterki związane z wyzwaniami natury religijnej i egzystencjalnej.

Temporalny wymiar procesu kształtowania tożsamości religijnej trafnie oddaje metafora podróży - dogmaty religijne jako najważniejszy z drogowskazów nie wyznaczają jednak jednoznacznie jej kierunku. Droga owej podróży przybiera kształt labiryntu - ustawiczne poszukiwanie wyjścia pozostaje w gestii ucznia. Dowodzą tego tytuły analizowanych podręczników, będące wizytówką ich koncepcji metodycznej: Die Reli-Reise, Spurenlesen, Miteinander auf dem Weg, Bismillah - Wir endecken den Islam, Kinder fragen nach dem Leben.

Adresat podręcznika jest traktowany jako aktywny wędrowiec - krytyczny i refleksyjny badacz tekstów religijnych oraz ludzkich postaw, mający prawo do popełniania życiowych błędów, odwoływania się do swoich doświadczeń. Zarazem jako że znajduje się on w fazie intensywnego rozwoju, zadania i polecenia z podręcznika wspierają naturalną ciekawość, wychodzą naprzeciw potrzebom doświadczania nowych i ekscytujących rzeczy. Syntetyczny opis „przystanków” na drodze poszukiwania siebie i swojej religijnej tożsamości, a także metodyczne credo tych podręczników dobrze ilustruje triada: pytaćposzukiwać - odkrywać (fragen - suchen - entdecken) (Zalewska 2018: 32).

W fazie inicjacyjnej (fragen) najważniejsze są pytania wynikające $\mathrm{z}$ dziecięcych wątpliwości i rozterek natury egzystencjalnej i religijnej, rodzące się pod wpływem tekstów z kart podręcznika lub zadawane przez jego autorów. Na etapie poszukiwań (suchen) liczy się grupowa lub indywidualna deliberacja, możliwość konfrontowania stanowisk, odwoływania się do własnych doświadczeń. Na etapie odkrywania (entdecken) formułuje się odpowiedzi, z zastrzeżeniem, że mogą one ulegać dalszym przeobrażeniem, nie są osta- 
teczne. Nietrudno dostrzec analogie występujące między opisaną procedurą a koncepcją hermeneutycznego koła; cykl pytanie - poszukiwanie - odkrywanie (odpowiedź) tworzy ramy konstrukcyjne wszystkich podręczników, wyznacza strukturę ich kolejnych rozdziałów. Wynika z samej natury życia zmuszającego nas do ciągłej refleksji, ujawnia się tu znaczenie religii jako przestrzeni autoidentyfikacji.

Klasyfikacje i przykłady pytań z kart podręcznika dotyczą następujących kwestii:

- stricte religijnych, związanych z podstawami wiary i ich osobistymi wykładniami oraz wątpliwości i rozterek wierzącego podmiotu: Co to jest wiara? Kim jest Jezus? Kto to jest Bóg? Czy możemy Boga zobaczyć, ustyszeć, odczuć jego obecność? Dlaczego nie widzimy Boga? Gdzie mieszka Bóg? Czy Bóg rzeczywiście jest wszędzie? Kto urodzit Boga? Co to dla ciebie oznacza, że Bóg stworzyt cię na swoje podobieństwo? Czy Bóg w ogóle istnieje? Dlaczego Bóg pozwala na wojny? Czy Bóg jest okrutny? Dlaczego Bóg zsyła na ludzi głód? (Kinder fragen nach dem Leben 1/2 2018; Miteinander auf dem Weg 3/4 2012);

- sfery profanum, złożonej natury świata, naszych zobowiązań wobec innych, motywów ludzkich postępków i nakazów religijnych jako wskazówek postępowania: Jak można pomagać innym? Co to znaczy, że wszyscy sa równi? Czy wszystkie ludzkie prawa sa sprawiedliwe? W jaki sposób człowiek może przejać odpowiedzialność za świat? (Spurenlesen 1/2 2016);

- osobistej sfery egzystencji ucznia poszukującego sensu życia i tworzącego obraz samego siebie: Rozważ, po co pojawiteś się na świecie? Skąd przychodzę, dokad idę? Kim jestem, co jest dla mnie ważne? Dlaczego jestem soba i nikim innym? Dlaczego czasem jestem smutny, a czasem wesoly? (Die Reli-Reise 1/2 2012) (Zalewska 2018).

Można zatem stwierdzić, że lekcje religii prowadzone z wykorzystaniem badanych podręczników stanowią okazję do głębokiej refleksji nas sobą, swoją wiarą, relacją z innymi. Zachęcając do namysłu i refleksji, podręczniki nie ingerują w te procesy, autorzy unikają indoktrynacji i moralizowania (tak charakterystycznych dla wielu polskich książek). Pojawia się nawet ikonka sygnalizująca, że nadszedł czas na formułowanie własnego stanowiska i jest ono niezwykle ważne: $W$ pytaniu oznaczonym tym symbolem ,,szczególnie ważne" sa twoje poglady. Powinieneś odpowiedzieć zgodnie z własnymi przekonaniami. Dominują następujące polecenia: przedyskutujcie, rozważcie, zastanówcie się, co byście poradzili w tej sytuacji, jak oceniasz taka postawe, jak rozumiesz to przestanie. Zawsze pojawia się również prośba o przytoczenie argumentów uzasadniających własne poglądy (Spurenlesen 3/4 2016).

Widoczna jest orientacja na podmiotowość dziecka, z zachowaniem jednak zasady równowagi między osobistym (indywidualnym) aspołecznym aspektem jego tożsamości religijnej, służy temu przede wszystkim wskazywanie na indywidualność i niepowtarzalność podmiotu jako niezbywalną i cenną (co jest zgodne z założeniami filozofii personalistycznej). Dowodzą tego tytuły rozdziałów podręcznika, np. Jesteś niepowtarzalny. Wiedzę osobistą i doświadczenia dziecka traktuje się jako ważne ramy interpretacyjne: $C z y$ przeżyłeś już taka sytuację? Jak wtedy postapiteś? (Fragen - suchen - entdecken 1/2 2015). 
Istotne jest także wspieranie krytycznej i refleksyjnej postawy w toku określania ludzkich powinności wobec Boga, siebie i innych. Jako przykład można wskazać zaproponowaną formułę pracy nad tekstem o próbie złożenia ofiary z własnego syna przez Abrahama. Zachęcając dziecko do wyrażania opinii, prosi się je także o wskazanie alternatywnego sposobu postępowania. Wynika to z dbałości o rozwój kompetencji krytycznych, umiejętności argumentowania i roztropnego wydawania osądu. Akcentując, że nikt nie powinien bać się Boga, ugruntowuje się w dziecku przekonanie, że ślepe posłuszeństwo wcale nie jest cnotą dobrego chrześcijanina czy muzułmanina. Nakazy i zakazy natury religijnej, tak ważne w funkcjonowaniu wierzącego podmiotu, są przywoływane w celu zachęcenia dziecka do ich samodzielnej interpretacji. Uznanie ich zasadności stanowi ważny krok w procesie internalizacji wartości zarówno religijnych, jak i ogólnoludzkich, w kształtowaniu sfery aksjologicznej. Dlatego sacrum i profanum jako płaszczyzny dziecięcych doświadczeń życiowych traktowane są integralnie. Epizody z życia rodziny, grupy rówieśniczej, klasy szkolnej, problemy współczesnego świata związane z migracjami, zanieczyszczeniem środowiska, głodem i przemocą pojawiają się w każdym podręczniku, stanowiąc punkt wyjścia do rozmów o zobowiązaniach wynikających tak z przynależności do ludzkiej, jak religijnej społeczności. Szacunek okazywany jednostce jako osobie charakteryzującej się niepowtarzalnym zbiorem cech nie usprawiedliwia egoizmu i samowoli - Inny powinien stanowić obiekt naszej troski. Przypowieść o dobrym Samarytaninie staje się okazją do rozmowy o potrzebie niesienia pomocy potrzebującym i okazywania współczucia ludziom znajdującym się w trudnej sytuacji (jako przykład zostali wymienieni uchodźcy) - przy tym celem jest nie tylko skłonienie dziecka do zadeklarowania takiej gotowości, ale przekonanie go do podjęcia stosownych działań: znalezienia w najbliższej okolicy organizacji zajmujących się działalnością charytatywną i ewentualnego zgłoszenia chęci współpracy z nią, niesienia pomocy osobom z najbliższego otoczenia itd.

$\mathrm{W}$ teoretycznej części pracy jako ważne wyzwanie i zadanie nauczania religii w polikonfesyjnym i polifonicznym społeczeństwie wskazano budowanie pozytywnej relacji z Innym. Szacunek dla innych oraz tolerancję wobec odmienności wskazano jako cechy dobrego chrześcijanina/muzułmanina, na szczególną uwagę jednak zasługuje formuła prezentacji innych konfesji: katolicyzmu/protestantyzmu, islamu oraz judaizmu. Profesjonalne i pogłębione portrety sporządzono na podstawie rzetelnych informacji o istocie konfesji i religijnych świętach, uzupełniono je bogatym zestawem ilustracji i fragmentami kanonicznych teksów. Dla ucznia jest to nie tylko ważna okazja do poznania innych religii i samodzielnego pogłębiania wiedzy o nich (np. szukania informacji w innych źródłach, odwiedzenia pobliskiego kościoła, meczetu czy synagogi, przygotowywania referatu itd.), ale także dostrzeżenie wpływu określonej religii na życie codzienne jej wyznawców (na dietę, ubiór, życie rodzinne, kulturę itd.), autorzy bowiem zadbali także o przekaz stosownych treści z tego zakresu. Być może dzięki takim zabiegom możliwe jest „oswojenie” tego, co dotychczas było inne i obce (wrogie), zrozumienie motywów i przyczyn zachowań przedstawicieli różnych konfesji. Jest to tym bardziej prawdopodobne, że pytania, zadania i polecenia pojawiające się $\mathrm{w}$ rozdziałach o nich są formułowane z założeniem poszukiwania „wspólnego rdzenia”, tego, co łączy wszystkie religie (pojawia się np. pole- 
cenie porównania pierwszej komunii i konfirmacji, imion proroków). Jednocześnie w żadnym podręczniku nie mamy do czynienia z jakąkolwiek próbą oceny prezentowanych konfesji. Dzieci korzystające z podręczników do nauczania religii ewangelickiej mogą się zapoznać zarówno $\mathrm{z}$ historyczną genezą tego wyznania i przyczynami rozłamu na gruncie chrześcijaństwa, jak i uświadomić sobie, że dogmaty religijne i generowane przez nie praktyki są także determinowane przez czynniki natury społecznej i kulturowej. Marcin Luter zostaje przedstawiony jako człowiek krytycznie nastawiony zarówno do wizji okrutnego i karzącego Boga, jak i działań kleru, który upowszechnia takie postrzeganie Boga i czerpie z tego korzyści. Promując postawy refleksyjne i odpowiedzialność za własne religijne poglądy, autor podręcznika proponuje dziecku zmierzenie się z pytaniem: Czy wola Boga było domaganie się oplat za grzechy? (Die Reli-Reise 3/4).

Ogromne znaczenie ma integralne traktowanie poznawczego, emocjonalnego i behawioralnego aspektu tożsamości religijnej, przy czym:

- wiedza o wybranej konfesji uznawana jest za dynamiczny system znaczeń, podlegający ewolucji na skutek nowych doświadczeń podmiotu i jego dojrzewania, traktuje się ją jako regulator działań wierzącej jednostki. Autorzy podręczników starają się tworzyć okazję do uruchomienia trybu interpretacyjnego w toku nabywania tej wiedzy przez ucznia, eksponowania jej funkcjonalnego charakteru (czego kwintesencję może stanowić pytanie: Co to znaczy być chrześcijaninem?); także siatka kategorialna stanowiąca rdzeń tożsamości religijnej powstaje w wyniku wspólnych lub samodzielnych rozważań, co umożliwia ich „oswojenie”; stworzony przez dziecko obraz Boga, jego definicja wiary, zbawienia, miłosierdzia stanowią ważny wynik wysiłków włożonych w kształtowanie własnej tożsamości religijnej;

- afektywny obszar tożsamości religijnej podlega także intensywnym oddziaływaniom podręcznika, osobiste doświadczenia i przeżycia religijne są traktowane jako bardzo ważne, nawiązuje się w nich do świąt celebrowanych w gronie rodzinnym, uroczystości kościelnych i spotkań ze wspólnotą, a także momentów zachwytu nad pięknem planety (jako dzieła boskiego). Prosi się ucznia o podzielenie się swoimi emocjami i odczuciami, a także o organizowanie uroczystości religijnych w klasie szkolnej (podczas Bożego Narodzenia, Wielkanocy itd.) - może to sprzyjać budowaniu więzi między ich uczestnikami; ekspresji uczuć religijnych sprzyjają także samodzielnie układane modlitwy;

- behawioralny komponent tożsamości religijnej związany z praktykami religijnymi oraz funkcjami pełnionymi przez podmiot we wspólnotach wyznaniowych i grupach społecznych jest stymulowany przez podręczniki bezpośrednio i pośrednio. Służą temu: wspomniane już propozycje organizacji wyjść do miejsc kultu, wycieczek do organizacji pomocowych itp., podejmowane działania o charakterze dobroczynnym, angażowanie się w wolontariat. Jednocześnie autorzy podręczników skoncentrowali się na rozwijaniu empatii uczniów - w zadaniach proszą o wczuwanie się w sytuację bohaterów z obszaru sacrum lub profanum, stających w obliczu dramatycznych wyborów, o udzielanie im rad i wskazówek. Choć mamy tu do czynienia jedynie z trybem hipotetycznym (Co byś zrobil, gdyby to dotyczyto 
ciebie?), takie ćwiczenia niewątpliwie odgrywają pozytywną rolę w skłanianiu do refleksji natury etycznej i egzystencjalnej, tak ważnej dla podejmowania decyzji we własnym życiu.

\section{Podsumowanie}

Zaprezentowana analiza upoważnia do sformułowania tezy o pozytywnej roli badanych podręczników jako swoistych narzędzi „profilaktyki” zagrożeń wynikających ze specyfiki procesu socjalizacji religijnej współczesnego ucznia. Podręczniki sprzyjają bowiem budowaniu relacji dziecko-religia opartej na osobistym odczytaniu jej przesłania oraz zrozumieniu jej znaczenia dla własnego życia. Ponieważ na tym etapie rozwoju dziecka decyzje o jego edukacji religijnej podejmują przede wszystkim rodzice, trudno nie docenić pozytywnego wkładu podręcznika w proces przekształcania (często) wymuszonego akcesu w uczestnictwo dobrowolne. Trzeba ponadto zauważyć, że autorzy podręczników unikają deklaratywności, oceniania, indoktrynacji i dydaktyzmu, religijnego fanatyzmu i banalizacji oraz infantylizacji, odnosząc się z szacunkiem do dziecięcych interpretacji religii i wysiłków zmierzających do budowania obrazu świata, ale wymagają także uzasadniania opinii i sądów wyrażanych przez dziecko. Skłaniają je do podejmowania intelektualnego wysiłku i refleksji etycznej, pracy nad sobą - przejmowania odpowiedzialności za swój rozwój. Zachęca się w nich do dialogu, traktując go jako preferowaną formę współistnienia, zarówno w ramach wspólnoty religijnej, jak i na gruncie międzywyznaniowym. Podręczniki odwołują się do wartości uniwersalnych i kompetencji kluczowych dla współczesnego człowieka, dzięki czemu traktują dziecko jako członka wielkiej wspólnoty ludzi, której trwanie zależy od solidarności i gotowości do współpracy.

\section{Literatura}

Berger P., Luckmann T. (1983), Społeczne tworzenie rzeczywistości. Warszawa, PIW.

Dobbelare K. (2012), Socjologiczna analiza definicji religii. W: W. Piwowarski (red.), Socjologia religii antologia tekstów. Kraków, Nomos.

Drobinski M., Schulte von Drach M. (2016), Wiesich der Religionsunterricht in Deutschland verändert hat. "SüddeutscheZeitung", 14 Juni 2016. https:/www.sueddeutsche.de/bildung/schulewie-sich-der-religionsunterricht-in-deutschland-veraendert-hat-1.2987758.

Herbatski A. (2015), Tożsamość religijna a bezpieczeństwo konfesyjne: współczesne wyzwania (na przykładzie republiki Białoruś). „Pogranicze. Studia Społeczne”, 25.

Höhne T. (2005), Schulbuchwissen. Umrisse einer Wissens - und Medientheorie des Schulbuches. Frankfurt am Mein, Hergestellt Books an Demand GmbH.

Kobzarska-Bar B. (2012), Tożsamość niemiecka w nowym tysiącleciu; leitkultur a islam. „Świat Idei i Polityki”, 12(14).

Krasowska J. (2013), Religia jako czynnik wpływająy na tożsamość narodowa Polaków. „Studia Sandomierskie: Teologia, Filozofia, Historia”, 20/21.

Milerski B. (2003), Pedagogika religii. W: Z. Kwieciński, B. Śliwerski (red.), Pedagogika. Podręcznik akademicki, t. 1. Warszawa, Wydawnictwo Naukowe PWN. 
Pankalla A., Wieradzka A. (2014), Ponowoczesna tożsamość religijna młodych Polaków z perspektywy koncepcji Jamesa Marcii i Koena Luyckxa. „Annales Universitatis Paedagogicae Cracoviensis. Studia Sociologica", 6.

Piechniczek T. (2015), Kultura i religijność w życiu miejskiej społeczności lokalnej. Socjologiczne studium przypadku. Kłodnica w Rudzie Śląskiej. Katowice, Studio Noa Ireneusz Olsza.

Polkowska A. (2001), Analiza dyskursu w badaniach zjawisk społecznych. W: I. Kurcz, J. Bobryk (red.), Psychologiczne studia nad językiem i dyskursem. Warszawa, Wydawnictwo Instytutu Psychologii PAN.

Różańska A. (2009), Dylematy kształtowania tożsamości religijnej młodzieży a edukacja religijna. W: M. Libiszowska-Żółtkowska (red.), Tożsamości religijne w społeczeństwie polskim. Socjologiczne studium przypadków. Warszawa, Difin.

Schweitzer F. (2005), Religiöse Identitätsbildung. W: P. Schreier, U. Sieg, E. Volker (hrsg.), HandbuchInterreligiöses Lernen. Guterslöh, Gutersloher Verlagshaus.

Szczyrba S. (2001), Tożsamość religijna czy osobowa? Przyczynek do filozofii dialogu międzyreligijnego i międzywyznaniowego. „Łódzkie Studia Teologiczne”, 10.

Wieradzka-Pilarczyk A. (2015), Tożsamość religijna młodych Polaków. Próba zastosowania koncepcji Koena Luyckxa w obszarze rozwoju religijnego. Poznań, Wydawnictwo Uniwersytetu im. Adama Mickiewicza.

Zalewska E. (2013), Obraz świata w podręcznikach szkolnych do klas początkowych. Gdańsk, Wydawnictwo Uniwersytetu Gdańskiego.

Zalewska E. (2018). Dialog jako podstawowy wymiar relacji w sferze sacrum i profanum w niemieckich podręcznikach do edukacji religijnej, „Przegląd Religioznawczy”, 3.

\section{Analizowane podręczniki}

Bismillah - Wir endecken den Islam (2012), Arbeitsheft 1/2, Weinheim, Schroedel Verlag.

Bismillah - Wirendecken den Islam (2012), Arbeitsheft 3, Wienheim, Schroedel Verlag.

Bismillah - Wirendecken den Islam (2012), Arbeitsheft 4, Weinheim, Schroedel Verlag.

Die Reli-Reise 1/2. Lehrwerkfür den evangelischen Religionsunterricht (2012), Stuttgart-Leipzig, Ernst Klett Verlag.

Die Reli-Reise 3/4 Lehrwerk für den evangelischen Religionsunterricht (2012), Stuttgart-Leipzig, Ernst Klett Verlag.

Fragen-suchen-entdecken 1/2. Katolische Religion in der Grundschule (2015), Stuttgart-Leipzig, Klett Verlag.

Fragen - suchen - entdecken 3/4. Katolische Religion in der Grundschule (2015), Stuttgart-Leipzig, KlettVerlag.

Kinder fragen nach dem Leben 1/2. Religionsbuch für die Grundschule (2018), Berlin, Cornelsen Verlag.

Kinder fragen nach dem Leben 3/4. Religionsbuch für die Grundschule (2018), Berlin, Cornelsen Verlag.

Miteinander auf dem Weg 1/2. Islamischer Religionsunterrich (2012), Stuttgart, Ernst Klett Verlag. Miteinander auf dem Weg 3/4. Islamischer Religionsunterricht (2012), Stuttgart, Ernst Klett Verlag. Spurenlesen. Religionsbuch für das 1/2. Schuljahr. Bayern (2016), Braunschweig, Diesterweg Verlag. Spurenlesen. Religionsbuch für das 3/4. Schuljahr. Bayern (2016), Braunschweig, Diesterweg Verlag. 